\title{
Synthesis of Medium Ring and Macrocyclic Acetylenic Lactones by the Ring Expansion of Oxabicycloalkenones
}

\author{
Jaswant Rai Mahajan*, and Inês Sabioni Resck \\ Department of Chemistry, University of Brasília, 70910-900 Brasília - DF, Brazil
}

Received: March 3, 1997

\begin{abstract}
Lactonas acetilênicas de tamanho médio e macrocíclico 15a-e [6-decin-9-olídeo (15a), 7-undecin-10-olídeo (15b), 8-dodecin-11-olídeo (15c), 12-hexadecin-15-olídeo (15d) e 5-decin-9olídeo (15e)] foram preparadas a partir de oxabiciclo-alquenonas 7a-d e $\mathbf{2}$, respectivamente, pela expansão de anel das tosil-hidrazonas 16a-e, efetuada pela reação com N-bromo-succinimida, sob condições rigorosamente controladas. A hidrogenação ( $\left.\mathrm{Pd}-\mathrm{C}, \mathrm{H}_{2}\right)$ completa da ligação tripla forneceu lactonas racêmicas saturadas: 9-decanolídeo (foracantolídeo I, 6, de 15a e 15e), 10-undecanolídeo, 11-dodecanolídeo (di-hidro-recifeiolídeo) e 15-hexadecanolídeo. As tentativas de converter di-hidropironas $\mathbf{7 a}$,d nas respectivas lactonas acetilênicas $\mathbf{1 5} \mathbf{a}, \mathrm{d}$, via cloro-hidrinas $\mathbf{8 a}$,d e/ou clorocetolactonas $\mathbf{9 a}, \mathrm{d}$, foram apenas parcialmente bem sucedidas.

Medium to macrocyclic acetylenic lactones 15a-e [6-decyn-9-olide (15a), 7-undecyn-10-olide (15b), 8-dodecyn-11-olide (15c), 12-hexadecyn-15-olide (15d), and 5-decyn-9-olide (15e)] were prepared from oxabicycloalkenones $\mathbf{7 a - d}$ and $\mathbf{2}$, respectively, by the ring expansion of their tosylhydrazones 16a-e, carried out by reaction with $\mathrm{N}$-bromosuccinimide, under strictly controlled conditions. Complete hydrogenation $\left(\mathrm{Pd}-\mathrm{C}, \mathrm{H}_{2}\right)$ of the triple bond gave the racemic saturated lactones: 9-decanolide (phoracantholide I, 6, from 15a and 15e), 10-undecanolide, 11-dodecanolide (dihydrorecifeiolide), and 15-hexadecanolide. The attempts at the conversion of dihydropyrones $\mathbf{7 a}, \mathrm{d}$ into the respective acetylenic lactones $\mathbf{1 5} \mathrm{a}, \mathrm{d}$, via chlorohydrins $\mathbf{8} \mathrm{a}, \mathrm{d}$ and/or chloroketolactones 9a,d, were only partially successful.
\end{abstract}

Keywords: acetylenic lactones, chloroketolactones, chlorohydrins, ring expansion, tosylhydrazones, fragmentation reaction

\section{Introduction}

Medium ring and macrocyclic lactones are important natural products and we have developed several methods for their synthesis ${ }^{1,2}$. Thus, in 1990, we described the preparation of desoxydiplodialide $\mathrm{D}(\mathbf{5})$ and phoracantholide I (6) from cyclohexane-1,3-dione ${ }^{3}(\mathbf{1})$ by a novel ring expansion of the vinylogous lactone intermediate $\mathbf{2}$, as illustrated in Scheme 1.

The success of this new ring enlargement protocol encouraged us to test its scope with several other oxabicycloalkenone systems shown in Scheme 2. While the process worked well with the dihydropyrones $7 \mathrm{a}, \mathrm{d}$, affording the corresponding chlorohydrins $\mathbf{8 a}, \mathrm{d}$ and subsequently the chloroketolactones $\mathbf{9 a}, \mathrm{d}$, it was not satisfactory with the phenolic substrates 11 to $\mathbf{1 4}$, which failed either to undergo a clean reaction with $\mathrm{HOCl}$ or satisfactory ring expansion to the desired chloroketolactone ${ }^{4}$. Apart from this lack of wide applicability, even in the successful cases (7a,d), the chloroketolactones $9 \mathrm{a}, \mathrm{d}$ were contaminated with the corresponding chlorohydrins $(\mathbf{8} \mathrm{a}, \mathrm{d})$ and did not undergo the reductive dechlorination ( $\mathrm{Zn}, \mathrm{AcOH}, \Delta$ or ultrasound $)^{4,5}$ to the desired ketolactones $10 \mathrm{a}, \mathrm{d}$, reverting instead to the starting vinylogous lactones $7 \mathrm{a}, \mathrm{d}$.

\section{Aims \& Objectives}

In the face of this failure, instead of looking for alternative methods for the removal of the chlorine atom, we thought it better to exploit its presence for the generation of a regiospecific triple bond according to a method, also under development in our laboratories ${ }^{6}$, whereby an $\alpha$ - 
chloroketo function is transformed into an acetylenic linkage, as depicted in Scheme 3. Moreover, it appeared mechanistically feasible to prepare the same acetylenic lactones 15a-d from the chlorohydrin 8a-d, as shown in item $\mathrm{C}$ of Scheme 3. Thus, we hoped to obtain the acetylenic lactones 15a-d from the respective mixtures, contain-<smiles>CC(C)CC1CCC2C(=O)CCC[C@@]2(C)O1</smiles>

Scheme 1. Synthesis of desoxydiplodialide D and phoracantholide I from dihydroresorcinol ${ }^{3}$.<smiles>CC1CC(=O)C2=C(CCCC2)O1</smiles>

7a,d

a: $\mathrm{n}=1 ; \mathrm{d}: \mathrm{n}=7$

B. Unsuccessful substrates<smiles>CC1(C)CC(=O)C2=C(C1)Oc1ccccc1C2</smiles>

12<smiles>CC1CC(=O)C2(Cl)CC=CCC2(O)O1</smiles>

8a,d

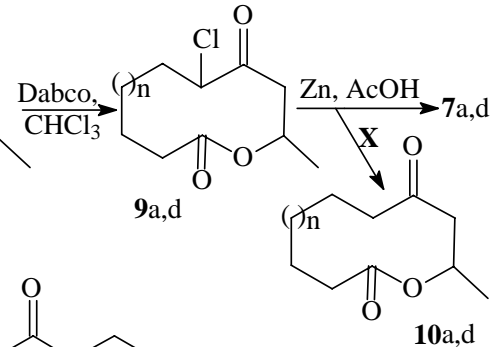

$10 \mathrm{a}, \mathrm{d}$<smiles>CC1(C)CC(=O)C2=C(C1)Oc1ccc3ccccc3c1C2</smiles><smiles>CC1(C)CCCc2c1c1cc[14c]3ccccc3c1oc2=O</smiles>

Scheme 2. Oxabicycloalkenones subjected to ring expansion via their chlorohydrins.
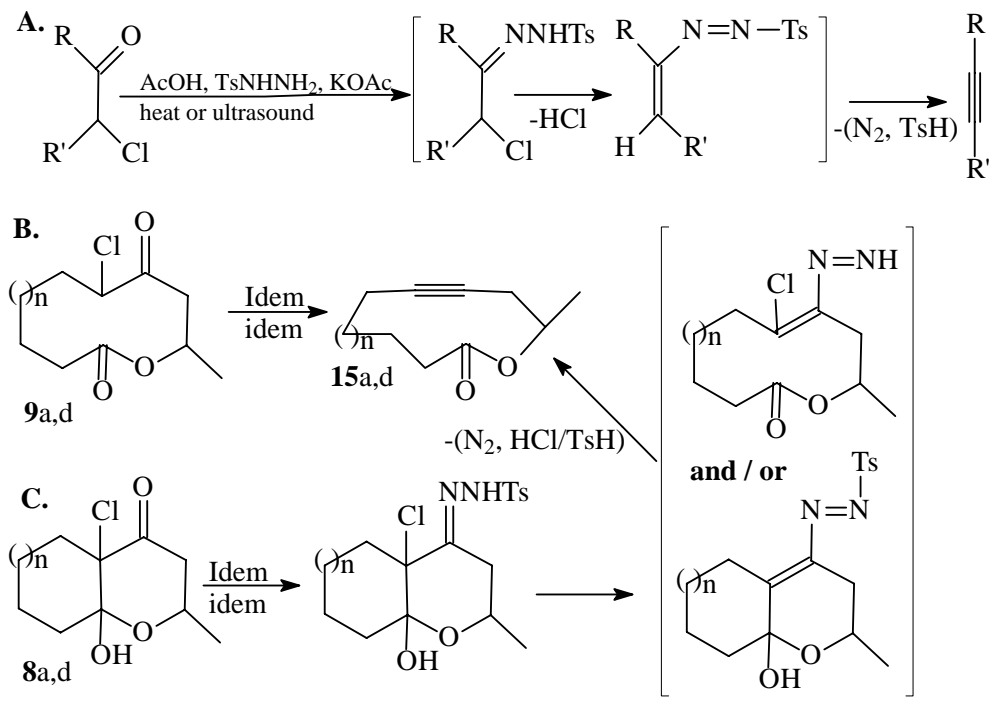

a: $\mathrm{n}=1 ; \mathrm{d}: \mathrm{n}=7$

Scheme 3. Conservion of $\alpha$-chlorlketones into acetylenic compounds. 
ing both the chlorohydrin (8a-d) and the chloroketolactone (9a-d).

Apart from this route, we also envisaged preparing the acetylenic lactones 15a-e from the heteroannular and homoannular oxabicycloalkenones $(\mathbf{2}, \mathbf{7 a}-\mathrm{d})$ via their tosylhydrazones (16a-e), involving a fragmentation reaction patterned after that of the bicycloalkenones ${ }^{7}$, as illustrated in Scheme 4. These expectations have been largely fulfilled $^{5,8-10}$ now and herein we describe the details of these investigations.

\section{Results and Discussion}

When we tried to prepare oxabicyclodecenone 7a by the known procedure ${ }^{11}$, involving the acylation of 1-morpholinocyclohexene with crotonyl chloride in the presence of triethylamine, followed by hydrolysis and basic isomerization of the resulting probable mixture (Scheme 5; brackets), we obtained only $30 \%$ of the desired product $7 \mathrm{a}$, instead of the $73 \%$ reported earlier ${ }^{11}$. However, on carrying out the isomerization/cyclization under acidic conditions (AcOH: $\mathrm{H}_{2} \mathrm{O}$ :conc. $\mathrm{HCl}, 1: 1: 1$ ), we could raise the yield to $75-80 \%$ (see Experimental).

Following this slightly modified procedure, we were also able to improve the yield of oxabicyclohexadecenone $7 \mathrm{~d}$ from the reported ${ }^{12} 16-19 \%$ to $30 \%$. Moreover, the melting point of our product, $54-56^{\circ} \mathrm{C}$, is much higher than that described earlier ${ }^{12}: 34{ }^{\circ} \mathrm{C}$.

However, even this improved procedure gave only poor yields in the case of cycloheptanone and cyclooctanone [7b (10\%), 7c (20\%)], and required chromatographic purification. Both $7 \mathrm{~b}$ and $7 \mathrm{c}$ are new compounds, having spectral (IR, ${ }^{1} \mathrm{H}-\mathrm{NMR}$ ) absorptions characteristic of the known oxabicycloalkenones $7 \mathrm{a}$ and $7 \mathrm{~d}$. Moreover, both gave the corresponding tosylhydrazone (16b, 16c), as described in the experimental part of this work.

The conversion of the vinylogous lactones $7 \mathrm{a}, \mathrm{c}, \mathrm{d}$ into the corresponding chlorohydrins $\mathbf{8 a}, \mathrm{c}, \mathrm{d}$ proceeded in almost quantitative yield, employing the household sodium

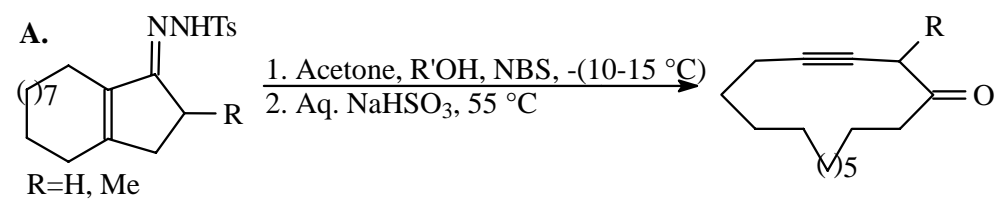

B.

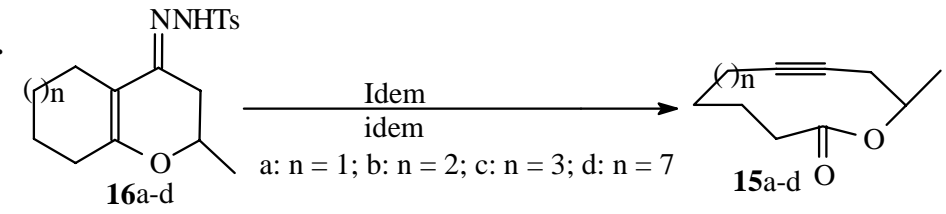

C.

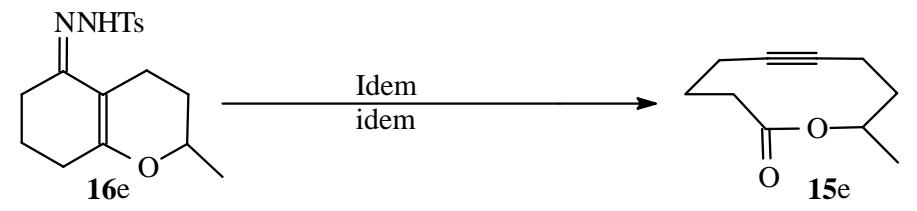

Scheme 4. Fragmentation reaction of tosylhydrazones of bicycloalkenones ${ }^{7,8}$.
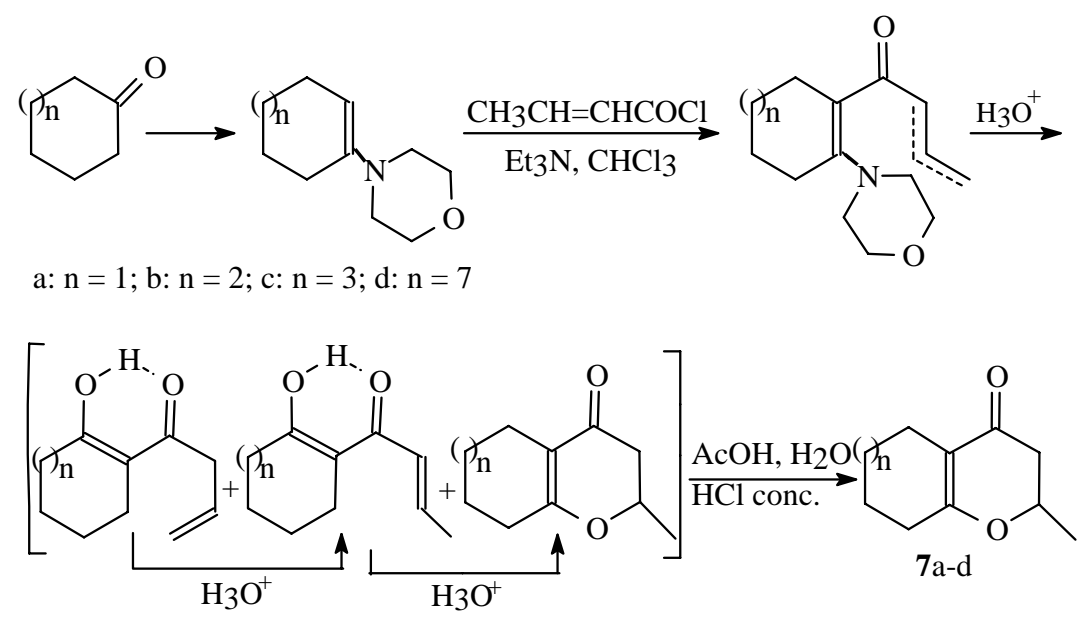

Scheme 5. Preparation of oxabicycloalkenones 7a-d from cycloalkanones. 
hypochlorite solution under slightly acidic conditions: Qboa, AcOH, EtOAc. In the case of 7a, a solid chlorohydrin fraction $8 \mathrm{a}$, free of chloroketolactone $9 \mathrm{a}$, could be isolated in $50 \%$ yield, but the other substrates furnished only gummy products, containing both the chlorohydrin and the corresponding chloroketolactone (TLC, IR, ${ }^{1} \mathrm{H}-\mathrm{NMR}$ ). The latter $(\mathbf{9} \mathrm{a}, \mathrm{c}, \mathrm{d})$ arise from the former $(\mathbf{8} \mathrm{a}, \mathrm{c}, \mathrm{d})$ by a retro-aldol reaction provoked, probably, during the basic washing of the reaction mixture with aq. $\mathrm{Na}_{2} \mathrm{CO}_{3}$.

Isomerization of the relatively pure chlorohydrin $\mathbf{8 a}$, or that of the mixtures $\mathbf{8 c}$,d, to the corresponding chloroketolactones 9a,c,d was conducted under mild conditions (DABCO, $\mathrm{CHCl}_{3}$, reflux) in order to avoid undesirable side reactions, such as the Favorskii rearrangement. The final product was slightly contaminated with the respective chlorohydrin and some unidentified byproducts (TLC, IR, ${ }^{1} \mathrm{H}-$ NMR).

In sharp contrast to the heteroannular and homoannular oxabicycloalkenones (2, 7a-d), the phenolic substrates $\mathbf{1 1}^{13}, \mathbf{1 2}^{-13}{ }^{14}$, and $14^{15}$ failed either to undergo a clean reaction with $\mathrm{HOCl}$ or posterior satisfactory ring expansion to the desired chloroketolactones (TLC, IR, ${ }^{1} \mathrm{H}-\mathrm{NMR}$ ).

The attempted reductive dechlorination $(\mathrm{Zn}, \mathrm{AcOH})$ of two such crude chloroketones $(\mathbf{9} \mathrm{a}, \mathrm{d})$, using heat or ultrasound $^{4,5}$, resulted in the recovery of the starting dihydropyrones $7 \mathrm{a}, \mathrm{d}$, instead of the desired ketolactones $\mathbf{1 0} \mathrm{a}$,d. The regeneration of the vinylogous lactones 7a,d involves, most probably, the intramolecular (transannular) acylation of the organo-zinc intermediate, in preference to its protonation, as encountered earlier ${ }^{3}$, albeit as a minor process, in our first example outlined in Scheme 1.

In the face of this failure, we tried to convert these chlorohydrins, or their mixture containing the respective chloroketolactones, into the corresponding acetylenic compounds $15 \mathrm{a}, \mathrm{c}, \mathrm{d}$, as pointed out earlier in the introductory section and illustrated in Scheme 3. However, the procedure was successful, only moderately, with the chlorohydrin 8a, affording the acetylenic lactone 15a in $~ 50 \%$ isolated yield, after chromatographic purification. In other cases, the reaction mixture showed a number of byproducts and only a small quantity of the desired acetylenic compound (TLC), whose laborious purification was deemed unnecessary, as, taking into account the fact that, in a concurrent study we had developed ${ }^{8}$ a novel and high-yield protocol for the preparation of acetylenic lactones 15a-e from tosylhydrazones 16a-e (Scheme 4 and vide infra).

Fortunately, the heteroannular and homoannular vinylogous lactones (2, 7a-d) furnished the corresponding tosylhydrazones (16a-e) under the standard conditions usually employed in the case of ordinary ketones: $\mathrm{MeOH}$, $\mathrm{TsNHNH}_{2}$, cat. $\mathrm{H}^{+}$, reflux. As mentioned earlier and illustrated in Scheme 4, their fragmentation reaction was patterned after that of the tosylhydrazones of some bicycloalkenones, described by the Swiss workers ${ }^{7}$ in

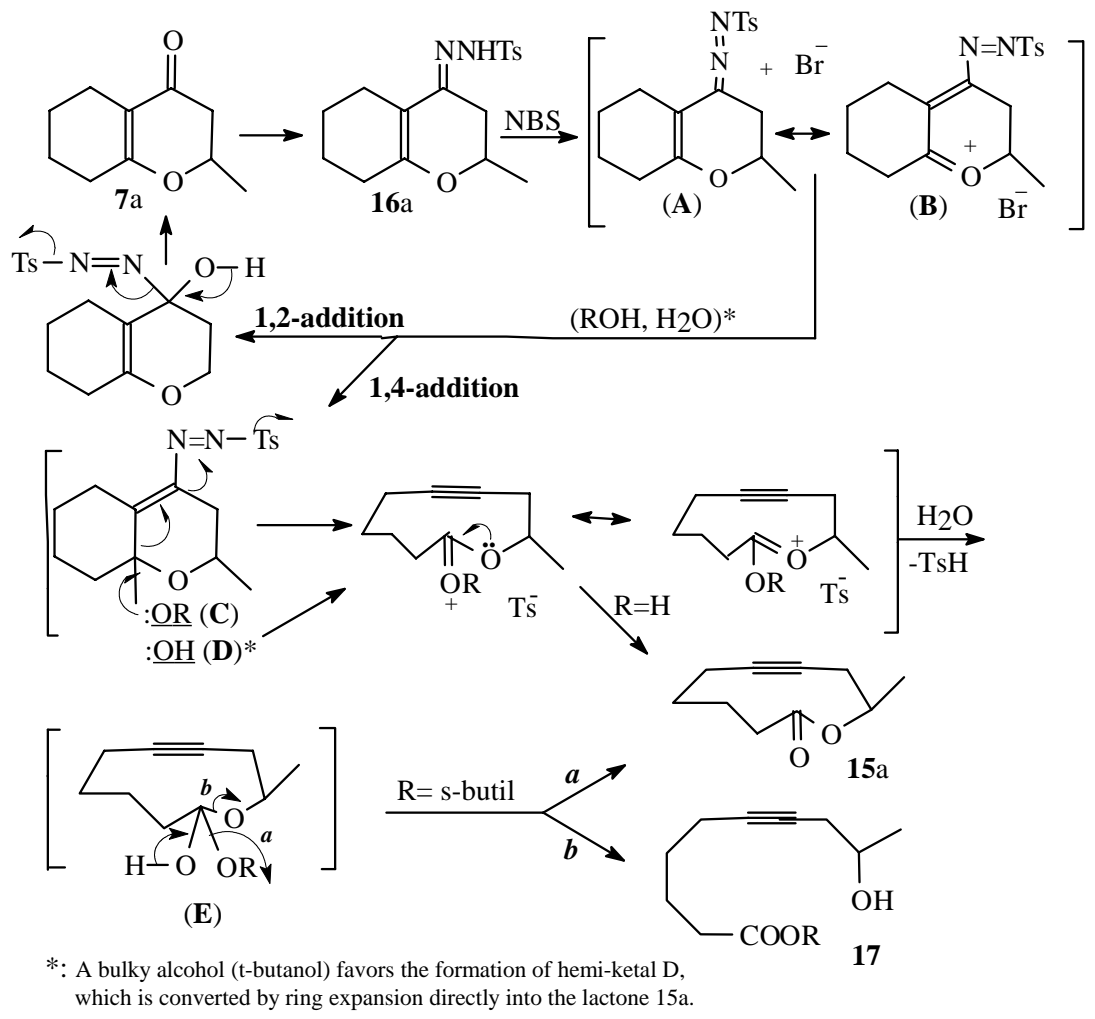

Scheme 6. Mechanism for the ring expansion of tosylhydrazones of oxabicycloalkenones ${ }^{8}$. 
1979. The success of the desired ring expansion depends vitally on the 1,4-addition of the nucleophile $\left(\mathrm{ROH}, \mathrm{H}_{2} \mathrm{O}\right)$ to the intermediate chemical species $\mathbf{A} / \mathbf{B}$, instead of the 1,2-addition which reverts them to the starting ketone, as illustrated for enone 7a in Scheme 6; incidently, the use of NBS for the regeneration of ketones from their tosylhydrazones was reported originally by Rosini ${ }^{16}$ in 1974 .

We would like to highlight here our preliminary but very instructive experiments with tosylhydrazone 16a. On carrying out its fragmentation reaction according to the recommended procedure ${ }^{7}\left(\mathbf{1 6} \mathrm{a}, 2-\mathrm{BuOH}\right.$, acetone, $-15^{\circ} \mathrm{C}$; $\mathrm{NBS},-15{ }^{\circ} \mathrm{C}$; aq. $\mathrm{NaHSO}_{3}, 55^{\circ} \mathrm{C}$, etc.), we obtained the desired lactone $15 \mathrm{a}$, contaminated with the expected starting enone 7a and some other minor impurities (TLC, IR, ${ }^{1} \mathrm{H}$-NMR). To improve the reaction, we next resorted to freshly crystallized and dessicator-dried NBS. To our surprise, the major product in this experiment turned out to be the 2-butyl hydroxy-ester (17) of the ring-opened lactone. Subsequently, chromatographic separation and spectral (IR, ${ }^{1} \mathrm{H}-\mathrm{NMR}$ ) identification of the reaction products proved them to be the starting enone $7 \mathrm{a}$, the desired lactone 15a, the hydroxy-ester 17, and 2-butyl tosylate 18. In fact, the last mentioned compound (18) was admixed with the acetylenic product 15a and could not be separated by chromatography or distillation. However, the spectral absorptions left no doubts about its identity. Nevertheless, we prepared an authentic sample of 2-butyl tosylate $(2-\mathrm{BuOH}$, $\mathrm{TsCl}$, pyridine) and found out that, apart from having the expected spectral signals, it had the same Rf as that of the acetylenic lactone $\mathbf{1 5}$ a.

The formation of 2-butyl tosylate requires some explanation. It could conceivably arise by the attack of 2-BuOH on the sulphonyl group of the reactive species $\mathbf{A} / \mathbf{B}$, or, most probably, by its tosylation with tosyl bromide ( $\mathrm{TsBr}$ ), generated from the byproduct $p$-toluenesulphinic acid (TsH) on reaction with the excess NBS present in the reaction mixture (Scheme 7).

The isolation of 2-butyl hydroxy-ester 17 proves inequivocally the 1,4-addition of the nucleophile (2-BuOH) to the reactive species $\mathbf{A} / \mathbf{B}$ and the intermediacy of the adduct $\mathbf{C}$, which after ring expansion (fragmentation) and the capture of a molecule of water, during the aqueous treatment, would lead to the hemi ortho-ester E. The latter can then afford either the desired lactone 15a or the unwanted hydroxy-ester 17 (Scheme 6).

Moreover, the formation of the 2-butyl hydroxy-ester $\mathbf{1 7}$ to suggested us that if we employed in the above reaction a small amount of water incorporated in a bulky alcohol

Table 1. ${ }^{13} \mathrm{C}$ Chemical Shifts of Acetylenic Lactones ${ }^{24} \mathbf{1 5}$ a-e.

\begin{tabular}{|c|c|c|c|c|c|}
\hline Compound: & $15 a^{*}$ & $15 b^{* *}$ & $15 c^{*}$ & $15 d$ & $15 \mathrm{e}^{*}$ \\
\hline Carbon & $\delta \mathrm{C}$ & $\delta \mathrm{C}$ & $\delta \mathrm{C}$ & $\delta \mathrm{C}$ & $\delta \mathrm{C}$ \\
\hline 1 & 173.76 & 173.15 & 173.46 & 173.29 & 174.60 \\
\hline 2 & 35.75 & 34.43 & 33.92 & 33.50 & 32.27 \\
\hline 3 & 23.91 & 24.91 & $24.87^{\mathrm{i}}$ & 25.54 & 24.63 \\
\hline 4 & $27.96^{\mathrm{i}}$ & 25.12 & $26.62^{\mathrm{i}}$ & $26.82^{\mathrm{i}}$ & $18.85^{\mathrm{p}}$ \\
\hline 5 & $18.80^{\mathrm{p}}$ & 24.63 & $26.24^{\mathrm{i}}$ & $27.76^{\mathrm{i}}$ & $83.47^{\mathrm{a}}$ \\
\hline 6 & $86.27^{\mathrm{a}}$ & $18.12^{\mathrm{p}}$ & $25.09^{\mathrm{i}}$ & $26.16^{\mathrm{i}}$ & $81.52^{\mathrm{a}}$ \\
\hline 7 & $79.42^{\mathrm{a}}$ & $82.76^{\mathrm{a}}$ & $17.42^{\mathrm{p}}$ & $26.20^{\mathrm{i}}$ & $16.41^{\mathrm{p}}$ \\
\hline 8 & $26.69^{\mathrm{p}, \mathrm{i}}$ & $77.66^{\mathrm{a}}$ & $82.10^{\mathrm{a}}$ & $26.97^{\mathrm{i}}$ & 34.81 \\
\hline 9 & $68.88^{\circ}$ & $26.69^{p}$ & $77.20^{\mathrm{a}}$ & $25.90^{\mathrm{i}}$ & $70.26^{\circ}$ \\
\hline 10 & $19.71^{\mathrm{m}}$ & $68.47^{\circ}$ & $24.04^{\mathrm{p}, \mathrm{i}}$ & $25.80^{\mathrm{i}}$ & $20.96^{\mathrm{m}}$ \\
\hline 11 & - & $19.99^{\mathrm{m}}$ & $69.07^{\mathrm{o}}$ & $18.08 \mathrm{p}$ & - \\
\hline 12 & - & - & $20.26^{\mathrm{m}}$ & $81.94^{\mathrm{a}}$ & - \\
\hline 13 & - & - & - & $75.33^{\mathrm{a}}$ & - \\
\hline 14 & - & - & - & $24.13^{p, i}$ & - \\
\hline 15 & - & - & - & $68.23^{\circ}$ & - \\
\hline 16 & - & - & - & $18.75^{\mathrm{m}}$ & - \\
\hline
\end{tabular}

*: Assignments based on PND and DEPT spectra at 300/75 Mhz.

**: Assignments based on PND, DEPT, ${ }^{1} \mathrm{Hx}{ }^{1} \mathrm{H}$ and ${ }^{1} \mathrm{Hx}^{13} \mathrm{C}$ COSY spectra at 200/50 MHz.

a: C-sp or C-acetylenic; m: Methyl; o: C-O; p: C-propargylic ( $\underline{\mathrm{C}}-\mathrm{C} \equiv \mathrm{C}-)$;

$\mathrm{i}$ : Interchangeable values, assigned according to the trends of the calculated values ${ }^{24}$. 


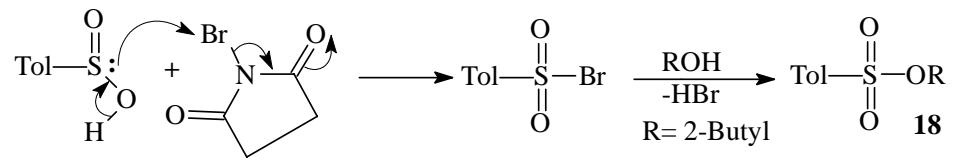

Scheme 7. Probable mechanism for the formation of 2-butyl tosylate.

$(\mathrm{t}-\mathrm{BuOH})$, there should result the intermediate hemi-ketal $\mathbf{D}$, instead of the mixed ketal $\mathbf{C}$, which upon ring expansion would transform directly into the desired acetylenic lactone 15a (Scheme 6). Consequently, we carried out the aforementioned reaction using a mixture of t-BuOH: $\mathrm{H}_{2} \mathrm{O}(9: 1)$. After the usual work-up and chromatographic purification, we obtained the product $15 \mathrm{a}$ in $90-95 \%$ yield. This improved procedure was then successfully employed for the preparation of other acetylenic lactones ${ }^{8}:$ 15b-d (85-95\%) and 15e (68\%).

To our surprise and disappointment, the tosylhydrazone ${ }^{17}$ of the phenolic subtrate $\mathbf{1 2}$ did not undergo the above fragmentation reaction satisfactorily; affording the recovered tosylhydrazone (mixed m.p.) along with a complex mixture of unidentified products.

Astonishingly, these acetylenic compounds (15a-e) showed no absorptions for the triple bond in the infrared region $\left(2200-2250 \mathrm{~cm}^{-1}\right)$, but their lactonic nature obvious both from their IR (1730-1735 $\left.\mathrm{cm}^{-1}\right)$ and ${ }^{1} \mathrm{H}-\mathrm{NMR}$ spectra (see Exptl). Thus, we hydrogenated these products to the saturated lactones: 9-decanolide or $( \pm)$-phoracantholide $\mathrm{I}^{3,18,19}(\mathbf{6})$, from both $15 \mathrm{a}$ and 15e, 10-undecanolide, 11-dodecanolide (dihydrorecifeiolide ${ }^{19,20}$ ), and 15-hexadecanolide $^{19,21,22}$. Subsequently, we obtained their Raman ${ }^{23}$ (see Exptl.) as well as ${ }^{13} \mathrm{C}-\mathrm{NMR}$ spectra ${ }^{24}$ (Table 1), which clearly diagnosed the triple bond $\left(2230-2235 \mathrm{~cm}^{-1}\right.$, medium; 2290-2295 $\mathrm{cm}^{-1}$, weak) and the sp carbon atoms (75-86 ppm).

The details regarding the conversion of these acetylenic lactones into the corresponding ethylenic compounds, containing either the $\mathrm{Z}$ or $\mathrm{E}$ double bond, has been reported ${ }^{10}$ recently as well as their transformation into the acyclic insect pheromones ${ }^{25}$.

In conclusion, it is very satisfying to record that we have been able to develop an efficient procedure for the preparation of medium to macrocyclic acetylenic lactones 15a-e from both the heteroannular and homoannular oxabicycloalkenones (2, 7a-d), via their tosylhydrazones 16a-e, involving a fragmentation/ring expansion reaction provoked by NBS, under strictly controlled conditions. The experimental details are given below.

\section{Experimental}

Reagent grade chemicals and solvents were used as received from the commercial suppliers, unless noted otherwise. All reactions were monitored routinely by thin layer chromatography (TLC: silica gel, revealed by $\mathrm{I}_{2}$ vapours).
Organic extracts were dried over anhydrous $\mathrm{Na}_{2} \mathrm{SO}_{4}$ and evaporated under reduced pressure on a rotary evaporator. Bransonic ultrasonic cleaner (Model 1210 or 2210; $47 \pm 6$ $\mathrm{KHz}$ ) was used to conduct some heterogeneous reactions. Temperatures in the short path distillations refer to the air bath. Chromatographic purifications were conducted by dry-column flash chromatography ${ }^{26}$ on silica gel (Merck, $60 \AA$ A 230-400 mesh). Melting points were determined on a Kofler block and are uncorrected. IR spectra of liquid samples (neat films) and solids (KBr disks) were recorded on a Nicolet 5ZDX-FT spectrometer. Raman spectra were obtained on Jarrel Ash spectrometer, model 25-300, or Jobin-Yvon instrument, model 1000, both using argon laser. Routine ${ }^{1} \mathrm{H}-\mathrm{NMR}$ spectra, reported in the experimental text were obtained on a Varian EM-390 $(90 \mathrm{MHz})$ instrument as $\mathrm{CCl}_{4}$ solutions, unless noted otherwise. The ${ }^{13} \mathrm{C}$ spectra of the acetylenic lactones were recorded in $\mathrm{CDCl}_{3}$ either at $300 / 75$ or $200 / 50 \mathrm{MHz}$, as shown in the Table 1. Gas chromatographic (GC) analyses were carried out on a Varian Aerograph, Model 1440, using 15\% FFAP column ( $3 \mathrm{~mm} \times 2 \mathrm{~m}$ ), at 210 to $230^{\circ} \mathrm{C}$, swept with $\mathrm{N}_{2}$ (40 $\mathrm{mL} / \mathrm{min}$ ). Other experimental details are given below.

The vinylogous lactone $\mathbf{2}$ was prepared as described earlier ${ }^{3}$. Enamines of 6-8 membered cycloalkanones were obtained according to the known procedure employing azeotropic removal (Dean-Stark) of water ${ }^{27,28}: 1$-morpholinocyclohexene, b.p. $115-116^{\circ} \mathrm{C} / \sim 6$ Torr (lit. ${ }^{27}$, b.p. 118 $120{ }^{\circ} \mathrm{C} / 10$ Torr); 1-morpholinocycloheptene, b.p. 85-86 ${ }^{\circ} \mathrm{C} / 0.5$ Torr (lit. ${ }^{28}$, b.p. $133-135^{\circ} \mathrm{C} / 17$ Torr); 1-morpholinocyclooctene, b.p. $106-108{ }^{\circ} \mathrm{C} / 0.5$ torr. 1-morpholinocyclododecene was prepared using titanium tetrachloride method ${ }^{29}$; a slightly yellowish viscous liquid, b.p. $142-144{ }^{\circ} \mathrm{C} / 0.5$ torr (lit. ${ }^{30}$, b.p. $125-130{ }^{\circ} \mathrm{C} / 0.05$ Torr).

Crotonyl chloride was prepared by a slight modification of the method described for the preparation of acriloyl chloride $^{31}$ : Thionyl chloride $(10 \mathrm{~mL}, 16.31 \mathrm{~g}, 137 \mathrm{mmol})$ was added to a magnetically stirred mixture of crotonic acid ( $8.6 \mathrm{~g}, 0.1 \mathrm{~mol})$, sulphur powder $(160 \mathrm{mg})$, cuprous chloride $(0.5 \mathrm{~g}, 5 \mathrm{mmol})$ and hydroquinone $(110 \mathrm{mg}, 1 \mathrm{mmol})$. There was a cooling of the reaction mixture and liberation of gas $\left(\mathrm{HCl}, \mathrm{SO}_{2}\right)$, which was captured in a water trap. Subsequently, the reaction mixture was refluxed for 3-4 $\mathrm{h}$ and distilled at atmospheric pressure, obtaining the crotonyl chloride as a colorless liquid (8.36-9.40 g; 80-90\%), b.p. 117-119 ${ }^{\circ} \mathrm{C}$ (lit. ${ }^{32}$, b.p. $\left.120-123^{\circ} \mathrm{C}\right)$. 


\section{Preparation of Oxabicycloalkenones 7a-d. General Procedure}

To a solution of 1-morpholinocycloalkene $(50 \mathrm{mmol})$ and triethylamine $(10.50 \mathrm{~mL}, 7.60 \mathrm{~g}, 75 \mathrm{mmol})$ in chloroform $(100 \mathrm{~mL})$, stirred magnetically and kept around $35^{\circ} \mathrm{C}$ (tap water), and under an anhydrous atmosphere of $\mathrm{N}_{2}$ $\left(\mathrm{CaCl}_{2}\right)$, was added, during $1 \mathrm{~h}$, a solution of crotonyl chloride $(6.23 \mathrm{~mL}, 6.79 \mathrm{~g}, 65 \mathrm{mmol})$ in chloroform $(50 \mathrm{~mL})$. The resulting reddish-brown mixture was kept on a warm water bath $\left(38-40{ }^{\circ} \mathrm{C}\right)$ for $24-36 \mathrm{~h}$, when dil. $\mathrm{HCl}$ $(50 \mathrm{~mL})$ and $95 \%$ ethanol $(10 \mathrm{~mL})$ were added and the mixture refluxed for 8-10 h, under vigorous stiring, to effect the hydrolysis. After cooling, the organic layer was separated and the aqueous portion $(\mathrm{pH} 1)$ was extracted with chloroform $(3 \times 50 \mathrm{~mL})$. The combined organic extract was washed succesively with distilled water $(3 \times 50 \mathrm{~mL})$, satd. solution of sodium bicarbonate $(50 \mathrm{~mL})$ and brine $(50 \mathrm{~mL})$. Drying and evaporation of solvent gave a reddish-brown liquid, which upon short path distillation, $110-120{ }^{\circ} \mathrm{C} / 0,5$ Torr, afforded a yellowish liquid, showing several spots on TLC. Thus, it was subjected to isomerization/cyclization reactions by refluxing, under stirring, for 4-6 $\mathrm{h}$ in a mixture of AcOH:Conc. $\mathrm{HCl}: \mathrm{H}_{2} \mathrm{O}$ (1:1:1) (1 mL of each component for $1 \mathrm{~g}$ of the distillate). The cooled reaction mixture was diluted with water $(20-30 \mathrm{~mL})$ and extracted with ethyl acetate $(3 \times 50 \mathrm{~mL})$. The combined extract was washed with distilled water $(3 \times 50 \mathrm{~mL})$, satd. solution of sodium bicarbonate $(50 \mathrm{~mL})$ and brine $(50 \mathrm{~mL})$. Drying and evaporation of solvent gave the crude product, which was purified as described for the individual members.

\section{2-Methyl-2,3-dihydro-5,6-tetramethylene-4-pyrone (7a)}

The crude product was a yellowish solid (5.81-6.64 g; 70-80\%), showing only one spot on TLC. Upon sublimation $\left(110-120^{\circ} \mathrm{C} / 5\right.$ Torr) or recrystallization from hexane, it furnished white needles (5.40-5.81 g; 65-70\%); m.p. $47-48{ }^{\circ} \mathrm{C}\left[\right.$ lit. $^{11}$ (73\%); p.f. $\left.46^{\circ} \mathrm{C}\right]$. IR (KBr) v: 1660,1612 $\mathrm{cm}^{-1} .{ }^{1} \mathrm{H}-\mathrm{NMR} \delta: 1.4\left(\mathrm{~d}, \mathrm{~J}=6 \mathrm{~Hz}, 3 \mathrm{H}, \mathrm{CH}_{3}\right), 1.43-2.00(\mathrm{~m}$, $\left.4 \mathrm{H}, 2 \mathrm{CH}_{2}\right), 2.0-2.6(\mathrm{~m}, 6 \mathrm{H}$, containing a doublet, $\mathrm{J} 7 \mathrm{~Hz}$, superimposed at $2.33,3 \mathrm{CH}_{2}$ ), 4.4 (split sextet, $1 \mathrm{H}, \mathrm{CH}$ ).

\section{2-Methyl-2,3-dihydro-5,6-pentamethylene-4-pyrone (7b)}

The crude product was a yellowish liquid ( $2.7 \mathrm{~g} ; 30 \%)$. It was purified by dry-column flash chromatography ${ }^{26}$ (silica gel, $15 \mathrm{~g}$; hexane:ethyl acetate (95:5)) and subsequently crystallized from hexane, furnishing a white solid (0.9 g; 10\%); m.p. 35-36 ${ }^{\circ} \mathrm{C}$. IR (KBr) v: 1652, 1601 $\mathrm{cm}^{-1} .{ }^{1} \mathrm{H}-\mathrm{NMR} \delta: 1.4\left(\mathrm{~d}, \mathrm{~J}=6 \mathrm{~Hz}, 3 \mathrm{H}, \mathrm{CH}_{3}\right), 1.43-1.90(\mathrm{~m}$, $\left.6 \mathrm{H}, 3 \mathrm{CH}_{2}\right), 1.9-2.7\left(\mathrm{~m}, 6 \mathrm{H}, 3 \mathrm{CH}_{2}\right), 4.4$ (split sextet, $1 \mathrm{H}$, $\mathrm{CH})$.

\section{2-Methyl-2,3-dihydro-5,6-hexamethylene-4-pyrone (7c)}

Yellowish liquid (3.9 g; 40\%) was chromatographed ${ }^{26}$ over silica gel $(20 \mathrm{~g})$, eluted with hexane:ethyl acetate9 (5:5), obtaining a colorless liquid (1.94 g; 20\%). IR (film) v: $1662,1609 \mathrm{~cm}^{-1} .{ }^{1} \mathrm{H}-\mathrm{NMR} \delta: 1.2-2.0(\mathrm{~m}, 11 \mathrm{H}$, having a doublet, $\mathrm{J}=6 \mathrm{~Hz}$, at 1.38 due to methyl, $\mathrm{CH}_{3}$ and $4 \mathrm{CH}_{2}$ ), 2.0-2.5 (m, $\left.6 \mathrm{H}, 3 \mathrm{CH}_{2}\right), 4.4$ (split sextet, $1 \mathrm{H}, \mathrm{CH}$ ).

Purification of the crude product by its conversion into the corresponding tosylhydrazone (vide infra), reproduced the same yield.

\section{2-Methyl-2,3-dihydro-5,6-decamethylene-4-pyrone (7d)}

Yellowish viscous liquid (5 g; 40\%) was crystallized from hexane, obtaining white needles $(3.75 \mathrm{~g} ; 30 \%)$; m.p. 54-56 ${ }^{\circ} \mathrm{C}$ [lit. ${ }^{12},(16-19 \%)$; m.p. $\left.34{ }^{\circ} \mathrm{C}\right]$. IR (KBr) v: 1657 , $1592 \mathrm{~cm}^{-1} .{ }^{1} \mathrm{H}-\mathrm{NMR} \delta: 1.0-1.9(\mathrm{~m}, 19 \mathrm{H}$, having the methyl doublet, $\mathrm{J}=6 \mathrm{~Hz}$, at $1.4, \mathrm{CH}_{3}$ and $\left.8 \mathrm{CH}_{2}\right), 1.9-2.6(\mathrm{~m}, 6 \mathrm{H}$, $3 \mathrm{CH}_{2}$ ), 4.33 (split sextet, $1 \mathrm{H}, \mathrm{CH}$ ).

\section{Preparation of Tosylhydrazones 16a-e. General Procedure}

A solution of vinylogous lactone 2 or oxabicycloalkenone 7a-d (5 mmol) and $p$-toluenesulfonylhydrazide $(1 \mathrm{~g}, 5,5 \mathrm{mmol})$ in methanol $(5 \mathrm{~mL})$, containing acetic acid or dil. $\mathrm{HCl}$ (1-2 drops), was refluxed gently on a water bath for 2-3 h. On cooling to room temperature, a slightly yellowish solid separated which was recrystallized from methanol.

\section{Tosylhydrazone 16 a}

White solid (1.53 g; 92\%), m.p. $165-167^{\circ} \mathrm{C}$. IR (KBr) v: $3202(\mathrm{NH}), 1636,1597,1405,1330,1161 \mathrm{~cm}^{-1} .{ }^{1} \mathrm{H}-$ NMR $\left(\mathrm{CDCl}_{3}\right) \delta: 1.1-1.8(\mathrm{~m}, 7 \mathrm{H}$, containing the methyl doublet, $\mathrm{J}=6 \mathrm{~Hz}$, at $1.27, \mathrm{CH}_{3}$ e $\left.2 \mathrm{CH}_{2}\right), 1.8-2.3(\mathrm{~m}, 4 \mathrm{H}$, $2 \mathrm{CH}_{2}$ ), 2.4 (s, $3 \mathrm{H}, \mathrm{H}_{3} \mathrm{C}$-arom.), 2.63 and 2.80 ( $2 \mathrm{~d}, \mathrm{~J} \sim 4 \mathrm{~Hz}$, $\left.2 \mathrm{H}, \mathrm{CH}_{2}\right), 3.7-4.2(\mathrm{~m}, 1 \mathrm{H}, \mathrm{CH}), 7.25$ and $7.85(2 \mathrm{~d}, \mathrm{~J} \sim 8 \mathrm{~Hz}$, $5 \mathrm{H}, 4 \mathrm{H}$-arom. and $\mathrm{NH}$ at 7.85 ).

\section{Tosylhydrazone $\mathbf{1 6} \mathrm{b}$}

White solid (0.87 g; 50\%), m.p. $140-142{ }^{\circ} \mathrm{C}$. IR (KBr) v: $3170(\mathrm{NH}), 1627,1600,1440,1409,1331,1171 \mathrm{~cm}^{-1}$. ${ }^{1} \mathrm{H}-\mathrm{NMR}\left(\mathrm{CDCl}_{3}\right) \delta: 1.0-1.8(\mathrm{~m}, 9 \mathrm{H}$, containig a doublet at $1,23, \mathrm{~J}=6 \mathrm{~Hz}$, due to methyl, $\mathrm{CH}_{3}$ and $\left.3 \mathrm{CH}_{2}\right), 1.8-2.8(\mathrm{~m}$, $9 \mathrm{H}$, having a singlet at $2.37, \mathrm{H}_{3} \mathrm{C}$-arom. and $\left.3 \mathrm{CH}_{2}\right), 3.7-4.2$ $(\mathrm{m}, 1 \mathrm{H}, \mathrm{CH}), 7.25$ and $7.85(2 \mathrm{~d}, 5 \mathrm{H}, 4 \mathrm{H}-$ arom. and $\mathrm{NH}$ superimposed at 7.85 ).

\section{Tosylhydrazone $16 c$}

Colorless solid (1.45 g; 80\%), m.p. $160-162{ }^{\circ} \mathrm{C}$. IR (KBr) v: $3161(\mathrm{NH}), 1627,1409,1392,1162 \mathrm{~cm}^{-1} .{ }^{1} \mathrm{H}-$ $\operatorname{NMR}\left(\mathrm{CDCl}_{3}\right) \delta: 1.1-1.8(\mathrm{~m}, 11 \mathrm{H}$, having a doublet, $\mathrm{J}=6$ 
$\mathrm{Hz}$, at $1.34, \mathrm{CH}_{3}$ and $\left.4 \mathrm{CH}_{2}\right), 1.8-2.9(\mathrm{~m}, 7 \mathrm{H}$, containing a singlet at $2.47, \mathrm{H}_{3} \mathrm{C}$-arom. and $\left.3 \mathrm{CH}_{2}\right), 2.66$ and $2.85(2 \mathrm{~d}$, $\left.\mathrm{J} 4 \mathrm{~Hz}, 2 \mathrm{H}, \mathrm{CH}_{2}\right), 3.8-4.3(\mathrm{~m}, 1 \mathrm{H}, \mathrm{CH}), 7.37$ and $7.98(2 \mathrm{~d}$, $\mathrm{J} 8 \mathrm{~Hz}, 5 \mathrm{H}, 4 \mathrm{H}$-arom. and $\mathrm{NH}$ at 7.98 ).

\section{Tosylhydrazone 16d}

Colorless solid (1.83 g; 87\%), m.p. $169-171{ }^{\circ} \mathrm{C}$. IR (KBr) v: $3205(\mathrm{NH}), 1615,1403,1320,1164 \mathrm{~cm}^{-1} .{ }^{1} \mathrm{H}-$ $\operatorname{NMR}\left(\mathrm{CDCl}_{3}\right) \delta: 1.0-1.8\left(\mathrm{~m}, 19 \mathrm{H}, \mathrm{CH}_{3}\right.$ and $\left.8 \mathrm{CH}_{2}\right), 1.8-2.8$ $\left(\mathrm{m}, 9 \mathrm{H}\right.$, containig a singlet at $2.42, \mathrm{H}_{3} \mathrm{C}$-arom. and $3 \mathrm{CH}_{2}$ ), 3.7-4.2 (m, $1 \mathrm{H}, \mathrm{CH}), 7.26$ and $7.82(2 \mathrm{~d}, \mathrm{~J} 8 \mathrm{~Hz}, 5 \mathrm{H}$, $4 \mathrm{H}$-arom. and $\mathrm{NH}$ at 7,26$)$.

\section{Tosylhydrazone 16e}

Colorless solid (1.49 g; 89\%); m.p. 175-176 ${ }^{\circ} \mathrm{C}$. IR (KBr) v: $3192(\mathrm{NH}), 1639,1404,1324,1164 \mathrm{~cm}^{-1} .{ }^{1} \mathrm{H}-$ $\operatorname{NMR}\left(\mathrm{CDCl}_{3}\right) \delta: 1.27\left(\mathrm{~d}, \mathrm{~J}=6 \mathrm{~Hz}, 3 \mathrm{H}, \mathrm{CH}_{3}\right), 1.3-2.0(\mathrm{~m}$, $\left.4 \mathrm{H}, 2 \mathrm{CH}_{2}\right), 2.0-2.3\left(\mathrm{~m}, 6 \mathrm{H}, 3 \mathrm{CH}_{2}\right), 2.42\left(\mathrm{~s}, 3 \mathrm{H}, \mathrm{H}_{3} \mathrm{C}-\right.$ arom.), $3.7-4.2(\mathrm{~m}, 1 \mathrm{H}, \mathrm{CH}), 7.28$ and $7.86(2 \mathrm{~d}, 5 \mathrm{H}, 4 \mathrm{H}-$ arom.and $\mathrm{NH}$ at 7,28).

\section{Preparation of Acetylenic Lactones 15a-e from Tosylhydrazones 16a-e. General Procedure}

To a stirred and cooled $\left(-10\right.$ to $\left.-15{ }^{\circ} \mathrm{C}\right)$ solution of tosylhydrazone 16a-e (5 mmol) in t-butanol:water $(9: 1 ; 20$ $\mathrm{mL})$ and acetone $(20 \mathrm{~mL})$ [16 $\mathrm{d}$ and $16 \mathrm{e}$ also required tetrahydrofuran $(20 \mathrm{~mL})]$ was added $N$-bromosuccinimide $(2 \mathrm{~g}, 11.23 \mathrm{mmol})$ in one portion. There was an immediate effervescent reaction and the mixture turned orange-yellow. After stirring for $15 \mathrm{~min}$, aqueous solution of $\mathrm{NaHSO}_{3}$ $(15 \mathrm{~mL} ; 2.7$ molar) was added, followed by water $(50 \mathrm{~mL})$ and the mixture heated for $1 \mathrm{~h}$ on a water bath kept at 50-60 ${ }^{\circ} \mathrm{C}$. After cooling, it was extracted with hexane $(3 \times 50 \mathrm{~mL})$, the combined extracts being washed successively with water $(3 \times 20 \mathrm{~mL})$, satd. solution of sodium bicarbonate (20 $\mathrm{mL}$ ) and brine $(20 \mathrm{~mL})$. Drying and evaporation of the solvent furnished the crude product as a yellowish liquid, in a quantitative yield, which was purified by dry-column flash chromatography ${ }^{26}$ and/or short-path distillation to obtain analytically pure sample, showing only one spot on TLC.

\section{6-Decyn-9-olide (15a)}

Was obtained as a colorless liquid $(0.74 \mathrm{~g} ; 89 \%)$ after chromatograhic $^{26}$ purification (silica gel, $15 \mathrm{~g}$; hexane:ethyl acetate (98:2)). IR (film) v: 1733, $1258 \mathrm{~cm}^{-1}$. Raman $v C \equiv C$ : 2232 (medium) and 2296 (week) $\mathrm{cm}^{-1}$. ${ }^{1} \mathrm{H}-\mathrm{NMR} \delta: 1.3\left(\mathrm{~d}, \mathrm{~J}=6 \mathrm{~Hz}, 3 \mathrm{H}, \mathrm{CH}_{3}\right), 1.33-3.70(\mathrm{~m}, 10 \mathrm{H}$, $5 \mathrm{CH}_{2}$ ), 5.35 (sextet, $\mathrm{J}=6 \mathrm{~Hz}, 1 \mathrm{H}, \mathrm{CH}$ ). GC (FFAP, 210 $\left.{ }^{\circ} \mathrm{C}\right)$ : Retention time 4' 04',.
Anal. Calcd. for $\mathrm{C}_{10} \mathrm{H}_{14} \mathrm{O}_{2}$ (166.2): C, 72.26; H, 8.49. Found C, 72.16; H, 8.45\%.

The higher field ${ }^{13} \mathrm{C}$ spectra of the acetylenic lactones ${ }^{24}$ 15a-e are shown in the Table 1.

\section{7-Undecyn-10-olide (15b)}

Short path distillation (110-120 ${ }^{\circ} \mathrm{C} / 5$ Torr) gave a colorless liquid $(0.77 \mathrm{~g} ; 85 \%)$. IR (film) v: $1735,1251 \mathrm{~cm}^{-1}$. ${ }^{1} \mathrm{H}-\mathrm{NMR} \delta: 1.2\left(\mathrm{~d}, \mathrm{~J}=6 \mathrm{~Hz}, 3 \mathrm{H}, \mathrm{CH}_{3}\right), 1.23-2.60(\mathrm{~m}, 12 \mathrm{H}$, $6 \mathrm{CH}_{2}$ ), 5.12 (sextet, $\mathrm{J}=6 \mathrm{~Hz}, 1 \mathrm{H}, \mathrm{CH}$ ).

\section{8-dodecyn-11-olide $(\mathbf{1 5}$ c)}

Was obtained as a colorless liquid $(0.9 \mathrm{~g}$; $93 \%)$, upon short path distillation (110-120 ${ }^{\circ} \mathrm{C} / 5$ Torr). IR (film) v: $1733,1250,1231 \mathrm{~cm}^{-1}$. Raman $v \mathrm{C} \equiv \mathrm{C}: 2235$ (medium) and 2291 (weak) $\mathrm{cm}^{-1} .{ }^{1} \mathrm{H}-\mathrm{NMR} \delta: 1.23$ (d, J $7 \mathrm{~Hz}, 3 \mathrm{H}, \mathrm{CH}_{3}$ ), 1.27-2.60 (m, 14H, 7 $\left.\mathrm{CH}_{2}\right), 5.1$ (sextet, $\mathrm{J}=6 \mathrm{~Hz}, 1 \mathrm{H}, \mathrm{CH}$ ). GC (FFAP, $220^{\circ} \mathrm{C}$ ): Retention time 5' 48'.

Anal. Calcd. for $\mathrm{C}_{12} \mathrm{H}_{18} \mathrm{O}_{2}$ (194.3): C, 74.19; H, 9.34. Found C, 73.91; H, 9.37\%.

\section{2-Hexadecyn-15-olide (15d)}

Having a characteristic musk odor, was obtained as a colorless oil (1.1 g; 88\%), after short path distillation at 110-120 ${ }^{\circ} \mathrm{C} / 0.5$ Torr. IR (film) v: $1734,1248,1224 \mathrm{~cm}^{-1}$. Raman $v \mathrm{C} \equiv \mathrm{C}: 2228$ (medium) and 2285 (weak) $\mathrm{cm}^{-1}$. ${ }^{1} \mathrm{H}-\mathrm{NMR} \delta$ : $0.8-1.9(\mathrm{~m}, 17 \mathrm{H}$, containing a doublet at 1.28 , $\mathrm{J}=6 \mathrm{~Hz}$, due to methyl, $\mathrm{CH}_{3}$ and $\left.7 \mathrm{CH}_{2}\right), 1.8-2.8(\mathrm{~m}, 8 \mathrm{H}$, $4 \mathrm{CH}_{2}$ ), 4.9 (deformed sextet, $1 \mathrm{H}, \mathrm{CH}$ ). GC (FFAP, $230^{\circ} \mathrm{C}$ ): Retention time 9' 05'.

Anal. Calcd. for $\mathrm{C}_{16} \mathrm{H}_{26} \mathrm{O}_{2}$ (250.4): C, 76.75; $\mathrm{H}, 10.47$. Found C, 76.57; H 10.41\%.

\section{5-Decyn-9-olide (15e)}

Chromatographic ${ }^{26}$ purification (silica gel, $15 \mathrm{~g}$; hexane:ethyl acetate (98:2)) furnished a colorless liquid (0.57 $\mathrm{g} ; 68 \%$ ). IR (film) v: 1728, 1265, $1216 \mathrm{~cm}^{-1}$. Raman $v \mathrm{C} \equiv \mathrm{C}$ : 2227 (medium) and 2290 (weak) $\mathrm{cm}^{-1} .{ }^{1} \mathrm{H}-\mathrm{NMR} \delta: 1.23$ (d, J $\left.7 \mathrm{~Hz}, 3 \mathrm{H}, \mathrm{CH}_{3}\right), 1.27-2.70\left(\mathrm{~m}, 10 \mathrm{H}, 5 \mathrm{CH}_{2}\right), 5.27$ (deformed sextet, J $7 \mathrm{~Hz}, 1 \mathrm{H}, \mathrm{CH})$. GC (FFAP, $210{ }^{\circ} \mathrm{C}$ ): Retention time 4' 27',

Anal. Calcd. for $\mathrm{C}_{10} \mathrm{H}_{14} \mathrm{O}_{2}$ (166.2): C, 72.26; H, 8.49. Found C, 72.53; H, 8.38\%.

\section{Preparation of Chlorohydrins 8a,c,d. General Method}

A solution of household sodium hypochlorite (Q-boa; 0.65-0.70 molar, $6 \mathrm{~mL}$ ) was added to a well-stirred solution of the oxabicycloalkenone $7 \mathrm{a}, \mathrm{c}, \mathrm{d}(1 \mathrm{mmol})$ in acetic acid $(1.5 \mathrm{~mL})$ and ethyl acetate $(15-20 \mathrm{~mL})$. After stirring at room temperature for 30-40 min, the organic phase was 
separated and washed successively with water $(2 \times 10 \mathrm{~mL})$, sodium carbonate solution $(10 \mathrm{~mL})$ and brine $(10-15 \mathrm{~mL})$. After drying and evaporation of the solvent, there was obtained a white solid (8a) or a slightly yellowish gum $(\mathbf{8 c}, \mathrm{d})$, in a quantitative yield, which was characterized as follow.

\section{Chlorohydrin $8 a$}

White solid (220 mg; 100\%), m.p. 92-125 ${ }^{\circ} \mathrm{C}$, was recrystallized from $\mathrm{CCl}_{4}$ furnishing white needles $(110 \mathrm{mg}$; 50\%); m.p. 92-103 ${ }^{\circ} \mathrm{C}$. IR (KBr) v: 3457, $1720 \mathrm{~cm}^{-1}$. ${ }^{1} \mathrm{H}-\mathrm{NMR} \delta: 1.35$ (d, J 7 Hz, 3H, $\mathrm{CH}_{3}$, ), 1.5-3.1 (m, 11H, containing a singlet at 2.4 due to the hydroxyl group, $\mathrm{OH}$ and $\left.5 \mathrm{CH}_{2}\right)$, 4.4-4.8 (m, $\left.1 \mathrm{H}, \mathrm{CH}\right)$.

Chlorohydrins $8 \mathrm{c}, \mathrm{d}$, apart from their own characteristic signals (see above for $\mathbf{8 a}$ ), also showed the lactonic absorptions corresponding to chloroketolactones $\mathbf{9 c}, \mathrm{d}$, as evidenced by their IR $\left(1735-1740 \mathrm{~cm}^{-1}\right)$ and ${ }^{1} \mathrm{H}-\mathrm{NMR}$ spectra: $\delta$ 5.0-5.1 (dd, $\mathrm{C} \underline{\mathrm{HCl}}$ ) and 5.2-5.5 (m, C$-\mathrm{H}-\mathrm{OCO}-)$. After a quick passage through a small column of Florisil $(2 \mathrm{~g})$ in $\mathrm{CH}_{2} \mathrm{Cl}_{2}(20-30 \mathrm{~mL})$, these were used in the next reactions.

\section{Transformation of $8 \mathrm{a}, \mathrm{d}$ into Chloroketolactones 9a,d}

A solution of the chlorohydrin $8 \mathrm{a}, \mathrm{d}(1 \mathrm{mmol})$ and 1,4-diazabiciclo[2,2,2] octane (DABCO, $30 \mathrm{mg}, 0.3 \mathrm{mmol}$ ) in $\mathrm{CHCl}_{3}(10 \mathrm{~mL})$ was refluxed gently on a water bath for 3-4 h. After cooling, the reaction mixture was washed with dil. hydrochloric acid ( $3 \times 10 \mathrm{~mL})$, satd. solution of sodium carbonate $(3 \times 10 \mathrm{~mL})$ and brine $(10 \mathrm{~mL})$. Drying and evaporation of the solvent gave a yellowish gum in a quantitative yield, which proved to be the desired chloroketolactone 9a,d, contaminated by the respective chlorohydrin $8 \mathrm{a}, \mathrm{d}$, as evidenced with their TLC, IR and ${ }^{1} \mathrm{H}-\mathrm{NMR}$ spectra (vide supra). The crude product was subjected to reductive dechlorination, as described below.

\section{Attempted Reductive Dechlorination of Chloroketolactone 9a, $\mathbf{d}^{33}$}

A mixture of the crude chloroketolactone 9a,d (2 $\mathrm{mmol})$, acetic acid ( $3 \mathrm{~mL})$, zinc powder $(0.5 \mathrm{~g})$, and ethanol $(3 \mathrm{~mL})$ was irradiated with ultrasound for $3 \mathrm{~h}$, after which TLC showed absence of the starting material. After dilution with ethyl acetate $(20-30 \mathrm{~mL})$ and filtration, the filtrate was washed with brine $(3 \times 10 \mathrm{~mL})$, satd. solution of sodium bicarbonate $(4 \times 10 \mathrm{~mL})$ and brine $(10 \mathrm{~mL})$ again. Drying and evaporation furnished a yellowish semi-solid (80-85\% yield), which proved to be a mixture, containing mainly the dihydropyrone 7a,d (TLC, IR, $\left.{ }^{1} \mathrm{H}-\mathrm{NMR}\right)$.

\section{Preparation of Acetylenic Lactone 15a from Chlorohydrin 8a}

Procedure A: A mixture of chlorohydrin 8 a (1.09 g, 5 mmol; free of chloroketolactone $9 \mathrm{a})$, potassium acetate (1 $\mathrm{g}, 10 \mathrm{mmol})$, acetic acid $(12.5 \mathrm{~mL})$ and $p$-toluenesulfonylhydrazide ( $1 \mathrm{~g}, 5.5 \mathrm{mmol}$ ) was heated on a water bath (80-90 C) for $14 \mathrm{~h}$, closed under a balloon. There was liberation of gas and an orange colored mixture was obtained. It was treated with water $(10-15 \mathrm{~mL})$ and extracted with hexane $(3 \times 50 \mathrm{~mL})$. The combined extract was washed successively with water $(3 \times 10 \mathrm{~mL})$, satd. solution of sodium carbonate $(2 \times 10 \mathrm{~mL})$ and brine $(10 \mathrm{~mL})$. Usual work-up gave a yellowish liquid (700 mg; 84\%), which on dry column chromatography ${ }^{26}$ (silica gel, $15 \mathrm{~g}$; hexane:ethyl acetate $(98: 2))$ furnished a colorless liquid (420 mg; 50\%), identical in all respects (TLC, IR and ${ }^{1} \mathrm{H}-\mathrm{NMR}$ ) with the acetylenic lactone $\mathbf{1 5} \mathrm{a}$, prepared from tosylhydrazone 16a (vide supra).

Procedure B: The reaction mixture described in Procedure A was subjected to ultrasound irradiation for $1 \mathrm{~h}$, there being liberation of gas and the mixture turned orange colored. It was worked-up and purified just as described in Procedure A. The lactone 15a was obtained in 50\% yield.

\section{Attempted Preparation of Acetylenic Lactones 15c,d from Chlorohydrins 8c,d}

Chlorohydrins $8 \mathrm{c}$ or $8 \mathrm{~d}$, contaminated with the corresponding chloroketolactone $9 \mathrm{c}$ or $9 \mathrm{~d}$, when subjected to the ring expansion protocol described in Procedure A or B above, resulted in a complex mixture of products, containing only a small quantity of the desired lactone $15 \mathrm{c}$ or $15 \mathrm{~d}$ (TLC, IR, ${ }^{1} \mathrm{H}-\mathrm{NMR}$ ), whose purification was deemed unworthy in face of their much better preparation from the respective tosylhydrazones, described earlier.

\section{Attempted Preparation of Acetylenic Lactone $15 a$ from Chloroketolactone $9 a$}

The crude chloroketolactone $9 \mathrm{a}$, obtained by the isomerization of chlorohydrin 8a (vide supra), when allowed to react according to Procedure $\mathbf{A}$ or $\mathbf{B}$ gave poor results in comparison to chlorohydrin $\mathbf{8}$ a, thus discouraging the extension of the methodology to other chloroketolactones.

\section{Catalytic Hydrogenation of the Acetylenic Lactones 15a-e to the Saturated Lactones. General Procedure}

The acetylenic lactones $\mathbf{1 5 a}$-e $(1 \mathrm{mmol})$ dissolved in hexane $(10 \mathrm{~mL})$, containing $10 \% \mathrm{Pd}-\mathrm{C}(20-30 \mathrm{mg})$, were hydrogenated in a Parr apparatus (2-3 atm) for 4-6 h, when there was no more starting material (TLC). After filtering 
the catalyst and evaporation of hexane, the saturated lactones were obtained as colorless liquids, in 95-100\% yield. Their other characteristics are described below.

(士)-Phoracantholide $I^{3,18,19}$ (6)

Was obtained both from lactone $15 \mathrm{a}$ and $15 \mathrm{~d}$. IR (film) v: $1727,1246 \mathrm{~cm}^{-1} .{ }^{1} \mathrm{H}-\mathrm{NMR} \delta: 1.28\left(\mathrm{~d}, \mathrm{~J}=6 \mathrm{~Hz}, 3 \mathrm{H}, \mathrm{CH}_{3}\right)$, 1.32-2.70 (m, 14H, 7CH $), 5.0$ (split sextet, $1 \mathrm{H}, \mathrm{CH}) . \mathrm{GC}$ (FFAP, $210^{\circ} \mathrm{C}$ ): Retention time 2' 12”.

(士)-Undecan-10-olide: IR (film) v: $1727,1253 \mathrm{~cm}^{-1}$. ${ }^{1} \mathrm{H}-\mathrm{NMR} \delta: 1.17\left(\mathrm{~d}, \mathrm{~J}=6 \mathrm{~Hz}, 3 \mathrm{H}, \mathrm{CH}_{3}\right), 1.2-2.1(\mathrm{~m}, 14 \mathrm{H}$, 7CH 2$), 2.1-2.6\left(\mathrm{~m}, 2 \mathrm{H}, \mathrm{CH}_{2}\right), 4.8-5.2(\mathrm{~m}, 1 \mathrm{H}, \mathrm{CH})$.

$( \pm)$-Dihydrorecifeiolide ${ }^{19,20}$ : IR (film) v: 1730, 1224 $\mathrm{cm}^{-1} .{ }^{1} \mathrm{H}-\mathrm{NMR} \delta: 1.15\left(\mathrm{~d}, \mathrm{~J}=6 \mathrm{~Hz}, 3 \mathrm{H}, \mathrm{CH}_{3}\right), 1.18-2.60$ $\left(\mathrm{m}, 18 \mathrm{H}, 9 \mathrm{CH}_{2}\right), 4.8-5.2(\mathrm{~m}, 1 \mathrm{H}, \mathrm{CH}) . \mathrm{GC}\left(\mathrm{FFAP}, 220^{\circ} \mathrm{C}\right)$ : Retention time 2' 33'.

(士)-5-Hexadecanolide ${ }^{19,21,22}$ : IR (film) v: 1732, 1249 $\mathrm{cm}^{-1} .{ }^{1} \mathrm{H}-\mathrm{NMR} \delta: 1.2\left(\mathrm{~d}, \mathrm{~J}=6 \mathrm{~Hz}, 3 \mathrm{H}, \mathrm{CH}_{3}\right), 1.23-2.10(\mathrm{~m}$, $\left.24 \mathrm{H}, 12 \mathrm{CH}_{2}\right), 2.1-2.4\left(\mathrm{~m}, 2 \mathrm{H}, \mathrm{CH}_{2}\right), 4.7-5.1$ (m, $\left.1 \mathrm{H}, \mathrm{CH}\right)$. GC (FFAP, $220^{\circ} \mathrm{C}$ ): Retention time 5' 59'.

\section{Acknowledgments}

We thank the Brazilian National Research Council (CNPq), the University of Brasília (UnB) and the "Fundação de Amparo à Pesquisa - DF" (FAP-DF) for partial support of this work. We also thank Prof. Hugo Clemente de Araújo (UnB) for preparing the phenolic substrates 11-13 and the tosylhydrazone of compound 12. Special thanks are due to the following: Prof. Yoshio Kawano (USP) for the Raman spectra of the acetylenic lactones; Prof. Raimundo Braz-Filho and Prof. Mário G. de Carvalho (UFRRJ) for the 200/50 MHz spectra; and Prof. Faruk José N. Aguilera (UFSC) for some of the elementary analyses.

\section{References}

1. Mahajan, J.R. J. Braz. Chem. Soc. 1996, 7, 297.

2. a)Stach, H.;. Hesse, M Tetrahedron 1988, 44, 1573; b) Hesse, M. In Ring Enlargement in Organic Chemistry; VCH; Weinheim, 1991; c) Trost, B.M.; Fleming, I., Eds.; Comprehensive Organic Synthesis: Selectivity, Strategy and efficiency in Modern Organic Synthesis; Pergamon Press; Oxford, 1991, Vol. 2; d) Roxburgh, C.J. Tetrahedron 1993, 49, 10749; ibid. 1995, 51, 9767; e) Rousseau, G. Tetrahedron 1995, 51, 2777.

3. Mahajan, J.R.; Silva, C.R. J. Braz. Chem. Soc. 1990, 1,87 .

4. Mahajan, J.R.; Resck, I.S.; Araújo, H.C.; Tresvenzol, L.M.F.; Aspesi, G.H. 15th Annual Meeting of $S B Q$ 1992, Abstracts: QO-09.

5. Resck, I.S. Ph.D Thesis, University of Brasília, Department of Chemistry, 1990.
6. a) Mahajan, J.R.; Tresvenzol, L.M.F. J. Braz. Chem. Soc. 1993, 4, 179; b) Mahajan, J.R.; Resck, I.S.; Aspesi, G.H. 17th Annual Meeting of SBQ 1994, Abstracts: QO-41.

7. Fehr, C.; Ohloff, G.; Buchi, G. Helv. Chim. Acta 1979, 62, 2655.

8. Mahajan, J.R.; Resck, I.S. J. Chem. Soc., Chem. Comm. 1993, 1748.

9. Mahajan, J.R.; Resck, I.S. 16th Annual Meeting of SBQ 1993, Abstracts: QO-22.

10. Mahajan, J.R.; Resck, I.S. Synth. Commun.1996, 26, 3809.

11. Gelin, R.; Gelin, S.; Dolmazon, R. Bull. Soc. Chim. Fr. 1973, 1409.

12. Hickmott, P.W.; Miles, G.J.; Sheppard, G.; Urbani, R.; Yoxall, C.T. J. Chem. Soc., Perkin Trans. I 1973, 1514.

13. Paquette, L.A.; Stucki, H. J. Org. Chem. 1966, 31, 1232.

14. a) Yates, P.; Bichan, D.J.; McCloskey, J.E. J. Chem. Soc., Chem. Commun. 1972, 839; b) Yates, P.; Bichan, D.J. Can. J. Chem. 1975, 53, 2045.

15. Sen, H.K.; Basu, U. J. Indian Chem. Soc. 1928, 5, 467; Chem. Abstr. 1929, 23, 383.

16. Rosini, G. J. Org. Chem. 1974, 39, 3504.

17. Tosylhydrazone (m.p. $240-242^{\circ} \mathrm{C}$ ) of the dimedone derivative 12 was prepared in the usual manner as described for its homolog in Ref. 14b.

18. a) Mahajan, J.R.; Araújo, H.C. Synthesis 1981, 49; b) Mahajan, J.R.; Araújo, H.C.; Resck, I.S. J. Braz. Chem. Soc. 1990, 1, 119.

19. a) Kostova, K.; Hesse, M. Helv. Chim. Acta 1984, 67, 1713; b) Milenkov, B.; Hesse, M.; ibid. 1986, 69, 1323.

20. Wang, J.W.; Verigin, V.; Oehlschlager, A.C.; Bordon, J.H.; Pierce, H.D.; Pierce, A.M.; Long, L. J. Chem. Ecol. 1983, 9, 451.

21. Kaiser, R.; Lamparsky, D. Helv. Chim. Acta 1978, 61, 2671.

22. Mahajan, J.R.; Araújo, H.C. Braz. Pat. PI 8108358, 1981; Chem. Abstr. 1984, 100, 138981k.

23. Mahajan, J.R.; Resck, I.S. 16th Annual Meeting of SBQ 1993, Abstracts: QO-144.

24. Mahajan, J.R.; Resck, I.S. 4th Meeting of NMR users 1993, Abstracts: p. 85; Anais, 319.

25. Mahajan, J.R.; Resck, I.S. J. Braz. Chem. Soc. 1997, $8,000$.

26. a) Harwood, L.M. Aldrichimica Acta 1985, 18, 25; b) Yau, E.K.; Coward, J.K. ibid 1988, 21, 106. 
27. Hunig, S.; Lücke, E.; Brenninger, W. Org. Synth., Coll. Vol. V; H. E. Baumgarten, H.E., Ed.; Wiley: New York, 1973, p 808.

28. Stork, G.; Brizzolara, A.; Landesman, H.; Szmuskovicz, J.; Terrel, R. J. Am. Chem. Soc. 1963, 85, 207.

29. White, W.A.; Weingarten, H. J. Org. Chem. 1967, 32, 213.

30. Hünig, S.; Buysch, H.J.; Hosch, H.; Lendle, W. Chem. Ber. 1967, 100, 3996. 31.a) Rehberg, C.E.; Dixon, M.B.; Fisher, C.H. J. Am. Chem. Soc. 1945, 67, 209. b) Stempel Jr., G.H.; Cross, R. P.; Fisher, C.H. J. Am. Chem. Soc. 1950, 72, 2299.

32. Aldrich Catalog Handbook of Fine Chemicals 19941995, p 390.

33. Mahajan, J.R.; Resck, I.S.; Araújo, H.C.; Tresvenzol, L.M.F.; Aspesi, G.H. 15th Annual Meeting of SBQ 1992; Abstracts: QO-009. 